Roscoche, L.F.; Medeiros, H.F.; Oliveira, J.M.; Paula, E.M.S.; Costa, L.M.; Oliveira, S.M. Análise da potencialidade turística do Tabuleiro do Embaubal (Senador José Porfírio, PA). Anais do VIII Congresso Nacional de Ecoturismo e do IV Encontro Interdisciplinar de Ecoturismo em Unidades de Conservação. Revista Brasileira de Ecoturismo, São Paulo, v.4, n.4, 2011, p. 538.

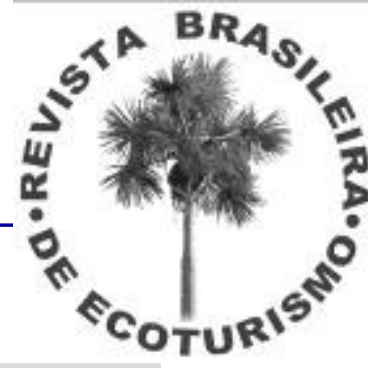

\title{
ANÁLISE DA POTENCIALIDADE TURÍSTICA DO TABULEIRO DO EMBAUBAL (SENADOR JOSÉ PORFÍRIO, PA)
}

\section{Luiz Fernando Roscoche*, Hermes Fonseca de Medeiros*, Janaina Melo Oliveira*, Eder Mileno Silva de Paula*, Leonardo Moura Costa*, Saloma Mendes Oliveira**}

\author{
*Universidade Federal do Pará, ** Secretaria de Meio Ambiente e Turismo de Senador José Porfírio \\ E-mails: luizfernando@ufpa.br, hermes@ufpa.br, janauece@gmail.com, edermileno@ufpa.br, \\ bioleon7@hotmail.com, saloma_oliveira@hotmail.com
}

O Tabuleiro do Embaubal é um arquipélago localizado no baixo Rio Xingu (Senador José Porfírio, PA), a $906 \mathrm{~km}$ da capital por via terrestre. É considerado área prioritária para conservação pelo Ministério de Meio Ambiente, pela diversidade biológica que abriga e por sua importância socioeconômica, incluindo seu potencial turístico. É composto por dezenas de ilhas cobertas com vegetação nativa, com poucas casas de ribeirinhos, em um trecho em que o Rio Xingu se alarga, apresentado águas calmas e limpas. Espécies atraentes para o turismo, como as duas espécies de boto, peixes-boi, jacarés e aves aquáticas são abundantes. O que mais tem chamado a atenção é a concentração da desova da tartaruga da Amazônia (Podocnemis expansa). Cardumes desta espécie, que chega a atingir $60 \mathrm{Kg}$, convergem de uma vasta região para poucas praias, onde 20.000 fêmeas depositam cerca de 1.800 .000 ovos, a maior concentração de ovos de que tartarugas de água doce das Américas. No inventário turístico do estado do Pará, o pólo Xingu, que inclui este arquipélago, foi considerado de grande potencial para turistas provenientes de outras regiões do Brasil e do Exterior. Apesar disto, praticamente inexiste exploração do turismo no local. A região está sofrendo mudanças aceleradas devido à implantação da Hidrelétrica de Belo Monte, uma das maiores hidrelétricas do mundo. Disto resultam aumento nas pressões para degradação da área, assim como a ampliação da infraestrutura necessária ao turismo. O objetivo desta pesquisa é reunir subsídios para o planejamento e gestão do turismo na região, com ênfase no ecoturismo e turismo técnico-científico, considerando que a área destina-se a conservação ambiental e, portanto, requer turismo de baixo impacto socioambiental e alto valor agregado. Num primeiro momento foram coletadas informações de caráter técnico e científico em um Workshop destinado a discussão de alternativas para o manejo e conservação da área, reunindo cientistas, órgãos públicos, ONGs e representantes da comunidade. Neste evento o ecoturismo foi reconhecido como uma alternativa de uso sustentável e geração de renda para a comunidade local, sendo identificados atrativos e áreas de maior potencial. Também foi realizada uma pesquisa exploratória não estruturada, baseada em expedições curtas, para o detalhamento e atualização de informações sobre a área, incluindo mapeamento, registro fotográfico e análise da área, identificando os possíveis pontos turísticos. Foram visitadas ilhas, cursos de água, lagoas, comunidades locais e um sítio arqueológico. Uma vantagem constatada deste arquipélago em relação a outras localidades amazônicas é a facilidade de acesso a partir de centros urbanos. Os atrativos do arquipélago estão a menos de meia hora de barco da sede de Senador José Porfírio, e a menos de uma hora e meia da sede de Altamira, onde existe uma maior oferta de serviços, incluindo um aeroporto com vôos regulares. A etapa subseqüente da pesquisa incluirá a aplicação de questionários estruturados sobre equipamentos, serviços e infra-estrutura turística do município de Senador José Porfírio, visando identificar a viabilidade da permanência de turistas no local.

Palavras-Chave: Potencial Turístico; Tabuleiro do Embaubal; Amazônia.

Apoio financeiro: WWF - Brasil. 